\title{
A systematic review of adherence to oral pre-exposure prophylaxis for HIV - how can we improve uptake and adherence?
}

\author{
David Sidebottom $^{1^{*}}$ (D), Anna Mia Ekström ${ }^{1,3}$ and Susanne Strömdahl $1^{1,2}$
}

\begin{abstract}
Introduction: Oral pre-exposure prophylaxis (PrEP) is an effective strategy to reduce the risk of HIV transmission in high risk individuals. However, the effectiveness of oral pre-exposure prophylaxis is highly dependent on user adherence, which some previous trials have struggled to optimise particularly in low and middle income settings. This systematic review aims to ascertain the reasons for non-adherence to pre-exposure prophylaxis to guide future implementation.

Methods: We performed structured literature searches of online databases and conference archives between August 8, 2016 and September 16, 2017. In total, 18 prospective randomized control trials and implementation studies investigating oral pre-exposure prophylaxis were reviewed. A structured form was used for data extraction and findings summarized regarding efficacy, effectiveness, adherence and possible reasons for non-adherence.

Results: Adherence varied between differing populations both geographically and socioeconomically. Common reasons for non-adherence reported over multiple studies were; social factors such as stigma, low risk perception, low decision making power, an unacceptable dosing regimen, side effects, and the logistics of daily life. Oral pre-exposure prophylaxis with included antiviral regimens was not associated with a high risk of antiviral resistance development in the reviewed studies.

Conclusion: Our findings indicate that oral pre-exposure prophylaxis should be delivered within a holistic intervention, acknowledging the other needs of the targeted demographic in order to maximise acceptability. Socioeconomic factors and poor governmental policy remain major barriers to widespread implementation of pre-exposure prophylaxis.
\end{abstract}

Keywords: HIV, Pre-exposure prophylaxis, HIV prevention, Systematic review, Medication adherence, Antiviral drug resistance

\section{Background}

In the face of barriers due to policy, stigma, and culture, progress is being made in the struggle against HIV. Antiretroviral therapy (ART) is undergoing rapid global scale-up with the 90-90-90 2020 United Nations (UN) target in sight, reaching $46 \%$ global coverage in 2015 compared to less than $10 \%$ the decade before [1]. This translates into a $26 \%$ reduction in global AIDS-related deaths since 2010. Additionally, with the efficacy of treatment as prevention demonstrated in 2011 [2], ART holds the potential to reduce HIV incidence beyond the 36.7 million

\footnotetext{
* Correspondence: dbsidebottom@gmail.com

${ }^{1}$ Department of Public Health Sciences, Karolinska Institutet, Stockholm,

Sweden

Full list of author information is available at the end of the article
}

people already infected. However, despite these advances, the Joint United Nations Programme on HIV/AIDS (UNAIDS) notes that recent headway in HIV incidence reduction has slowed "alarmingly", and that disparities in progress are widening for certain key populations such as young women, sex workers, people who inject drugs (PWID) and men who have sex with men (MSM) [1].

It is within these key populations that the burden of HIV is disproportionately carried. The risk of HIV acquisition versus the general population is 10 times greater in sex workers and 24 times greater in PWID and MSM [3], although analysis reveals large diversity between regions. In Western Europe and North America, 49\% of new infections occur within the MSM population and $15 \%$ in PWID, whereas in Eastern Europe and Central

(C) The Author(s). 2018 Open Access This article is distributed under the terms of the Creative Commons Attribution 4.0 International License (http://creativecommons.org/licenses/by/4.0/), which permits unrestricted use, distribution, and 
Asia the figures are 6 and 51\% respectively [1]. This variation reflects the diverse burden of stigma and discrimination borne by these populations [4]. Same-sex acts are illegal in $72(37 \%)$ UN states, and punishable by the death penalty in $13(6 \%)$ [4], just one example of the many additional challenges faced by individuals and organisations battling HIV. Effective prevention strategies to combat HIV are desperately needed by these hidden populations, none more so than transgender women (TGW), who have nearly 49 times greater odds of HIV acquisition than the general population [5].

In $2010 \mathrm{iPrEx}$ became the first randomised controlled trial (RCT) to demonstrate the efficacy of pre-exposure prophylaxis (PrEP) in MSM, finding a 44\% risk reduction in the experimental group receiving daily oral tenofovir-emtricitabine (TDF-FTC) as compared to placebo [6]. This success has since been replicated in several further studies encompassing both daily [7-9] and on-demand regimens [10], fuelling global excitement over this novel strategy. Following this data, PrEP is recommended for implementation among MSM by the World Health Organisation (WHO) and the Centres for Disease Prevention and Control (CDC) [11, 12]. However, failures have been observed in some at-risk groups, most notably heterosexual women $[13,14]$.

Previous literature notes that adherence is a critical link in the wider PrEP continuum, and that the success of PrEP intervention rides on its ability to maintain good adherence within the cohort under investigation [15, 16]. In 2013, a nested sub-study of the Partners trial found that high $(>80 \%)$ PrEP adherence was associated with 100\% PrEP efficacy (95\% CI 83.7 to 100\%) [17]. Conversely, in 2015 the VOICE trial failed to demonstrate PrEP clinical effectiveness in young African women [14], where only $30 \%$ of quarterly plasma samples contained a detectable level of TDF. Whilst a number of reviews exist concerning various aspects of PrEP we conducted this global systematic review to assess adherence to oral PrEP in the context of the reported efficacy. We also aimed to discuss the reasons for non-adherence in detail to guide comprehensive PrEP implementation programming in the future.

\section{Methods}

\section{Search strategy and inclusion criteria}

The Population, Intervention, Comparison, Outcome (PICO) framework was used to develop the search strategy. The population was defined as all individuals 'at risk' of HIV acquisition that have been studied regarding PrEP. Eligible studies comprised of prospective RCTs and implementation studies that examined efficacy, effectiveness or adherence. Both studies reporting oral TDF and TDF-FTC as the intervention were included as this distinction has not been shown to be clinically important $[7,18]$. Daily, event and time driven regimens were all eligible (Fig. 1). The outcomes assessed were efficacy and adherence. For adherence all measurements were included. All comparison and no-comparison trials were included. In practice the 'at risk' population is reflected in trial recruitment criteria, so was not specified in our search. No restrictions were imposed regarding geographical location, sex or gender, sexual preference, or dosing regimen. Only English language trials discussing oral PrEP efficacy, effectiveness or adherence in detail were included.

We performed online searches in Ovid Medline (without revisions, 1996 to current), Web of Science, EMBASE and the Cochrane Library. An initial search was conducted in August 2016, and repeated in September 2017. In addition, we searched conference abstracts from the AIDS Conference, International AIDS Society Conference and the Conference on Retroviruses and Opportunistic Infections via their online archives.

Our search utilised a combination of medical subject heading terms (denoted by appended ' $/$ ') and keywords as follows; (Pre-Exposure Prophylaxis/ OR PrEP OR chemoprophyla* OR antiretroviral prophyla*) AND (HIV/ OR HIV-1/ OR Anti-HIV Agents/). Results were limited to 'human' and 'clinical trial', from 2010 to 'current' as the first PrEP RCT was published in 2010.

\section{Screening and data extraction}

Published studies were identified through the search strategy described above, and titles were screened for relevance. Abstracts were further screened for eligibility and downloaded for further analysis when inclusion criteria were met. Identified articles were critically appraised using a checklist [19] to assess methodology prior to inclusion into the systematic review. Attention was paid to randomisation and blinding adequacy, allocation concealment and loss to follow up.

An initial online search on August 8, 2016 located 87 potentially relevant papers, and one conference abstract. A repeated search on September 15, 2017 located an additional 35 papers, and 12 conference abstracts. In total, 18 papers and 10 conference abstracts were found. DS extracted the data using a structured form regarding study design and population, geographical location and time, sample size, follow-up time, drug regimen, efficacy measurement, and adherence measurements. An additional 5 papers reported on qualitative exploration of factors affecting PrEP adherence. Authors were contacted by email if clarification was required.

All adherence measurements used were included, as defined in cited literature. Detection of TDF and/or FTC in plasma is highly concordant with the presence of TDF/FTC active metabolites within HIV-1 target cells, which provides protection from HIV $[6,20]$. Tenofovir 


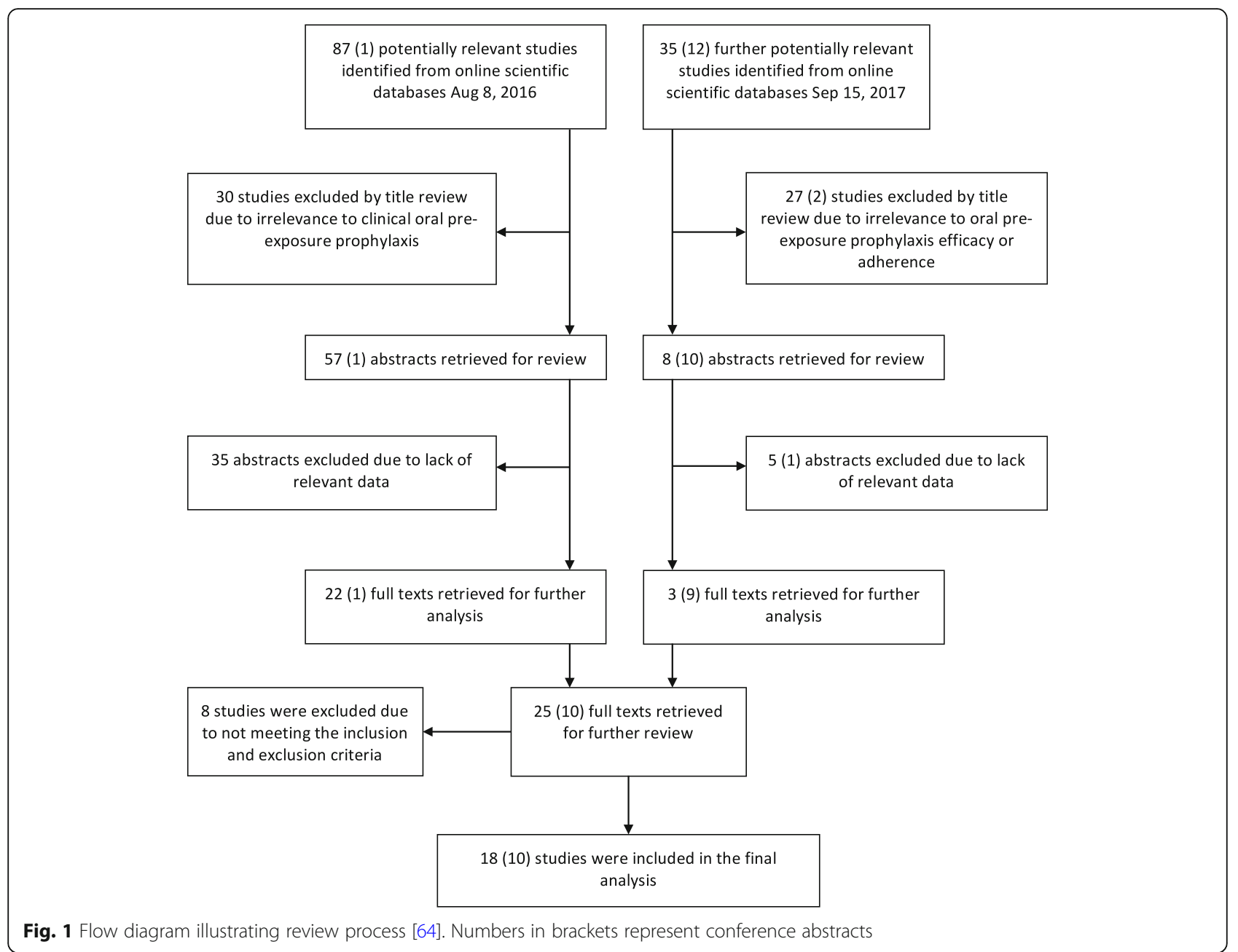

diphosphate levels, measured through dried blood spot testing, is increasingly used as an intrusive biomarker of long-term PrEP adherence, due to its long half-life of 17 days $[15,21]$. However, a variety of soft adherence measures are also used (pill count, self-report, medication event monitoring systems (MEMS). Where adherence at multiple time points was available, the latest measurement was taken, as maintaining prolonged adherence to PrEP throughout the duration of possible exposure to HIV is arguably of most clinical interest. Efficacy data was also extracted from the literature, as this important outcome is best understood in the context of reported adherence.

\section{Results}

Study design is illustrated in Fig. 1. Randomised controlled trials have evaluated oral PrEP in a variety of geographical and sociological settings. The characteristics of included trials are displayed in Table 1.

\section{Adherence}

Table 2 describes reported study adherence by various measures. Wide disparity exists between soft (self-report, pill count, medication event monitoring system) and intrusive (levels of TDF and/or FTC in plasma samples, or tenofovir diphosphate measured in dried blood spots) measures of adherence. In all measured cases, a higher proportion of non-seroconverters have detectable plasma TDF than seroconverters. Two trials which failed in young African women are associated with poor adherence. Only $24 \%$ of non-seroconverters had detectable TDF in FEM-PrEP [13], and 29\% in VOICE [14]. In contrast, results from a series of recent open label papers and abstracts suggest high adherence in a variety of real-world settings [22-30].

Reported reasons for poor adherence are described in Fig. 3. Start-up symptoms, including nausea, vomiting, and dizziness, that lessen after the first month of medication, have been explicitly reported by several trials $[6,8,13,31]$. Low risk perception is also 
Table 1 Overview of included studies examining the efficacy, effectiveness, and adherence of oral PrEP

\begin{tabular}{|c|c|c|c|c|c|c|c|c|c|c|c|}
\hline \multicolumn{9}{|c|}{ Characteristics } & \multicolumn{3}{|c|}{$\begin{array}{l}\text { Number of incident } \\
\text { HIV infections }\end{array}$} \\
\hline Year & Study name & $\begin{array}{l}\text { Geographical } \\
\text { location }\end{array}$ & Population & Sample size & $\begin{array}{l}\text { Total follow-up } \\
\text { time } \\
\text { (person-years) }\end{array}$ & Design & Regimen & Drug & Study drug & $\begin{array}{l}\text { Placebo/ } \\
\text { comparator }\end{array}$ & Total \\
\hline 2010 & iPrEx [6] & Global & MSM/TGW & 2499 & 3324 & RDBPCT & Daily & TDF-FTC & 36 & 64 & 100 \\
\hline \multirow[t]{2}{*}{2012} & \multirow{2}{*}{$\begin{array}{l}\text { Partners } \\
\text { study [7] }\end{array}$} & \multirow{2}{*}{$\begin{array}{l}\text { Kenya and } \\
\text { Uganda }\end{array}$} & \multirow{2}{*}{$\begin{array}{l}\text { Heterosexual HIV- } \\
\text { discordant couples }\end{array}$} & \multirow[t]{2}{*}{4758} & \multirow[t]{2}{*}{7820} & \multirow[t]{2}{*}{ RDBPCT } & \multirow[t]{2}{*}{ Daily } & TDF-FTC & 13 & \multirow[t]{2}{*}{52} & \multirow[t]{2}{*}{82} \\
\hline & & & & & & & & TDF & 17 & & \\
\hline 2012 & TDF2 [8] & Botswana & Heterosexual & 1219 & 1563 & RDBPCT & Daily & TDF-FTC & 9 & 24 & 33 \\
\hline 2012 & FEM-PrEP [13] & $\begin{array}{l}\text { Kenya, } \\
\text { Tanzania } \\
\text { and } \\
\text { South Africa }\end{array}$ & $\begin{array}{l}\text { Heterosexual } \\
\text { females }\end{array}$ & 2120 & - & RDBPCT & Daily & TDF-FTC & 33 & 35 & 68 \\
\hline \multirow[t]{2}{*}{2012} & \multirow{2}{*}{$\begin{array}{l}\text { Kenya } \\
\text { safety and } \\
\text { adherence } \\
\text { study [38] }\end{array}$} & \multirow[t]{2}{*}{ Kenya } & \multirow{2}{*}{$\begin{array}{l}\text { MSM and Female } \\
\text { sex workers }\end{array}$} & \multirow[t]{2}{*}{72} & \multirow[t]{2}{*}{-} & \multirow[t]{2}{*}{ RDBPCT } & Daily & \multirow[t]{2}{*}{ TDF-FTC } & 0 & \multirow[t]{2}{*}{1} & \multirow[t]{2}{*}{1} \\
\hline & & & & & & & Time-driven & & 0 & & \\
\hline \multirow[t]{2}{*}{2013} & \multirow{2}{*}{$\begin{array}{l}\text { Partners } \\
\text { adherence } \\
\text { substudy [17] }\end{array}$} & \multirow{2}{*}{$\begin{array}{l}\text { Kenya and } \\
\text { Uganda }\end{array}$} & \multirow{2}{*}{$\begin{array}{l}\text { Heterosexual } \\
\text { HIV-discordant } \\
\text { couples }\end{array}$} & \multirow[t]{2}{*}{1147} & \multirow[t]{2}{*}{807} & Convenience & Daily & TDF-FTC & 0 & 14 & 14 \\
\hline & & & & & & $\begin{array}{l}\text { sub-conort } \\
\text { of a RDBPCT }\end{array}$ & & TDF & 0 & & \\
\hline 2013 & $\begin{array}{l}\text { Bangkok } \\
\text { tenofovir } \\
\text { study [31] }\end{array}$ & Bangkok & PWID & 2413 & 9665 & RDBPCT & Daily & TDF & 17 & 33 & 50 \\
\hline 2013 & Uganda & Uganda & Heterosexual & 72 & - & RDBPCT & Daily & TDF-FTC & 0 & 0 & 0 \\
\hline & $\begin{array}{l}\text { adherence } \\
\text { study [35] }\end{array}$ & & couples & & & & Time-driven & & 0 & 0 & \\
\hline 2013 & ATN 082 & United States & Young MSM & 58 & - & $\mathrm{RBPCT}$ & Daily & TDF-FTC & 0 & 0 & 0 \\
\hline & PrEPARE) [54] & & & & & & & No pill & 0 & & \\
\hline 2014 & $\begin{array}{l}\text { iPrEx } \\
\text { extension [15] }\end{array}$ & Global & MSM/TGW & $\begin{array}{l}1603 \\
\text { (1225 received) }\end{array}$ & - & Open Label & Daily & TDF-FTC & 28 & 13 & 41 \\
\hline 2015 & VOICE [14] & South Africa, & Heterosexual & 3019 & 4253 & $\mathrm{RCT}$ & Daily & TDF-FTC & 61 & 60 & 173 \\
\hline & & $\begin{array}{l}\text { Uganda, } \\
\text { Zimbabwe }\end{array}$ & temales & & & & & TDF & 52 & & \\
\hline 2015 & HPTN 067/ & South Africa & Heterosexual & 191 & - & RCT with & Daily & TDF-FTC & 1 & N/A & 5 \\
\hline & & & & & & regimens as & Time-driven & & 2 & & \\
\hline & & & & & & comparators & $\begin{array}{l}\text { Event- } \\
\text { driven }\end{array}$ & & 2 & & \\
\hline 2015 & $\begin{array}{l}\text { Generating } \\
\text { adherence } \\
\text { Philadelphia } \\
\text { [50] }\end{array}$ & United States & $\begin{array}{l}\text { Young MSM of } \\
\text { colour }\end{array}$ & 23 & 7.5 & Observational & Daily & TDF-FTC & 0 & N/A & 0 \\
\hline 2015 & PROUD [9] & $\begin{array}{l}\text { United } \\
\text { Kingdom }\end{array}$ & MSM & 544 & 465 & $\begin{array}{l}\text { RCT with } \\
\text { a } 1 \text { year } \\
\text { deferred } \\
\text { group as } \\
\text { comparator }\end{array}$ & Daily & TDF-FTC & 3 & 20 & 23 \\
\hline 2015 & IPERGAY [10] & $\begin{array}{l}\text { France and } \\
\text { Canada }\end{array}$ & MSM/TGW & 400 & 431 & RDBPCT & $\begin{array}{l}\text { Event- } \\
\text { driven }\end{array}$ & TDF-FTC & 2 & 14 & 16 \\
\hline 2016 & $\begin{array}{l}\text { Bangkok } \\
\text { MSM }^{\mathrm{a}}[55]\end{array}$ & Thailand & MSM /TGW & 168 & - & Observational & Daily & TDF-FTC & 0 & N/A & 0 \\
\hline 2016 & $\begin{array}{l}\text { Permanente } \\
\text { Cohort [24] }\end{array}$ & USA & At-risk & 972 & 850 & Open label & Daily & TDF-FTC & 0 & 2 Off-PrEP & 2 \\
\hline 2016 & $\begin{array}{l}\text { The Demo } \\
\text { Project [23] }\end{array}$ & USA & MSM/TGW & 557 & 481 & Open label & Daily & TDF-FTC & 1 & 1 Off-PrEP & 2 \\
\hline 2017 & SPARK $^{\mathrm{a}}[57]$ & United States & MSM & 301 & - & Open Label & Daily & TDF-FTC & - & - & - \\
\hline 2017 & $\begin{array}{l}\text { IPERGAY } \\
\text { extension [22] }\end{array}$ & $\begin{array}{l}\text { France/ } \\
\text { Canada }\end{array}$ & MSM/TGW & 361 & 518 & Open label & $\begin{array}{l}\text { Event- } \\
\text { driven }\end{array}$ & TDF-FTC & 0 & 1 Off-PrEP & 1 \\
\hline
\end{tabular}


Table 1 Overview of included studies examining the efficacy, effectiveness, and adherence of oral PrEP (Continued)

\begin{tabular}{|c|c|c|c|c|c|c|c|c|c|c|c|}
\hline \multicolumn{9}{|c|}{ Characteristics } & \multicolumn{3}{|c|}{$\begin{array}{l}\text { Number of incident } \\
\text { HIV infections }\end{array}$} \\
\hline Year & Study name & $\begin{array}{l}\text { Geographical } \\
\text { location }\end{array}$ & Population & Sample size & $\begin{array}{l}\text { Total follow-up } \\
\text { time } \\
\text { (person-years) }\end{array}$ & Design & Regimen & Drug & Study drug & $\begin{array}{l}\text { Placebo/ } \\
\text { comparator }\end{array}$ & $\overline{\text { Total }}$ \\
\hline 2017 & $\begin{array}{l}\text { Short term } \\
\text { PrEP } \\
\text { Mozambique } \\
{[25]}\end{array}$ & Mozambique & $\begin{array}{l}\text { Heterosexual } \\
\text { females }\end{array}$ & 74 & 7.4 & Open label & Daily & TDF-FTC & 0 & $N / A$ & 1 \\
\hline 2017 & $\begin{array}{l}\text { Parisian } \\
\text { MSM }^{\mathrm{a}}[26]\end{array}$ & France & MSM & 785 & 215 & Open label & $\begin{array}{l}\text { Daily \& } \\
\text { Event- } \\
\text { driven }\end{array}$ & TDF-FTC & 3 & N/A & 3 \\
\hline 2017 & $\begin{array}{l}\text { PRELUDE }{ }^{a} \\
{[27,28]}\end{array}$ & Australia & $\begin{array}{l}\text { Gay/bisexual } \\
\text { males }\end{array}$ & 317 & 381 & Open label & Daily & TDF-FTC & 0 & N/A & 0 \\
\hline 2017 & $\begin{array}{l}\text { PROUD } \\
\text { adherence }^{\text {a }} \\
\text { [29] }\end{array}$ & UK & MSM & $\begin{array}{l}544 \text { enrolled } \\
\text { (481 initiated) }\end{array}$ & 1253 & Open label & Daily & TDF-FTC & 10 & N/A & 10 \\
\hline 2017 & Pluspills ${ }^{a}$ [30] & South Africa & Adolescents & 148 & 131 & Open label & Daily & TDF-FTC & 0 & 1 Off-PrEP & 1 \\
\hline 2017 & $\begin{array}{l}\text { Brazil } \\
\text { Demo }^{a}[65]\end{array}$ & Brasil & MSM/TGW & 450 & 389 & Open label & Daily & TDF-FTC & 0 & 2 Off-PrEP & 2 \\
\hline
\end{tabular}

${ }^{a}$ Abstract available only. MSM men who have sex with men, TGW transgender women, $P W I D$ people who inject drugs, $R C T$ randomised controlled trial, $R D B P C T$ randomised, double blinded, placebo controlled trial, TDF tenofovir, FTC emtricitabine

reported to be a common issue. Many studies report challenges aligning perceived risk with actual risk [13, 14, 32-34]. Participants described concern regarding perceived long term side effects in two studies [32, 33 ] and poor adherence was partly attributed to dosing regimen in five studies [32, 33, 35-37]. However, a recent study of MSM in Toronto found that high versus low actual HIV risk were more willing to take PrEP (OR 27.11; 95\% CI, 1.33 to 554.43) [33].

Societal factors were repeatedly stated as major challenges to maintaining adherence. Governmental and policy factors were mentioned in several contexts, and stigma was reported by many participants in both quantitative and qualitative studies as a barrier to success [17, 38].

\section{Efficacy}

Reported efficacy is highly variable (Table 3), with overall HIV incidence relative risk reduction (RRR) ranging from -49 to $86 \%[9,10,14]$. Both RCTs reporting non-significant RRRs were conducted in the population of young African women [13, 14]. Efficacy among MSM has been consistently high, with recent implementation studies in the UK and Canada both reporting a RRR of $86 \%$ in real-life clinical deployment $[9,10]$. Heterosexual couples have also achieved high PrEP efficacy with the 2012 Partners study reporting a 75\% RRR over 7820 person-years of follow up. Within the single trial in PWID, overall RRR was found to be 48.9 (95\% CI, 9.6 to $72.2 \%$ ).

Three main oral dosing regimen options have been investigated (Fig. 2). Daily dosing is the most frequently tested regimen, with 9 of 11 independent RCTs choosing this route. In event-driven dosing, individuals take two tablets prior to intercourse, followed by single doses 24 and $48 \mathrm{~h}$ after the first [10]. Only 1 independent randomised controlled trial, IPERGAY, has evaluated the efficacy of the event-driven regimen so far. Despite only $43 \%$ of participants meeting optimum adherence criteria, IPERGAY found an on-treatment RRR of $86 \%$, on par with the daily regimen. Furthermore, mean pill use was halved with participants only using 15 pills per month, versus 30 per month with daily dosing. Time driven dosing, where individuals take pills twice weekly with a post-intercourse boost, has also been evaluated for safety and adherence $[35,36,38]$. This success was replicated in an open label extension, which found 97\% (95\% CI 81 to 100) effectiveness [22].

When analysis is limited to participants with detectable study-drug serum concentrations, efficacy is higher without exception $[6-8,10,31]$ reaching $92 \%$ in the $\mathrm{iPrEx}$ study subgroup. In an open label extension of iPrEx, no participants with plasma TDF concentrations consistent with 4 or more pills per week underwent seroconversion [15]. The two trial arm participants to undergo HIV seroconversion returned 60 and 58 pills out of 60 for pill count, so were seemingly non-adherent.

\section{Emergence of resistance in patients}

Several trials report individuals who were infected between enrolment and randomisation [7, 9, 14], or had missed diagnoses of pre-existing HIV infection [8], and were later randomised to receive PrEP [Table 4]. Fem-PrEP reported 4 cases of resistance to FTC (3 cases of the M184 V mutation, 1 case of the M184I mutation) in trial-arm participants. VOICE reported FTC resistance in 2 women infected between enrolment and randomisation (2 cases of M184 V/I), and 1 woman 
Table 2 Adherence to oral PrEP by different measures used

\begin{tabular}{|c|c|c|c|c|c|c|c|c|c|}
\hline \multicolumn{5}{|c|}{ Characteristics } & \multicolumn{5}{|l|}{ Adherence } \\
\hline \multirow[t]{2}{*}{ Year } & \multirow[t]{2}{*}{ Study name } & \multirow[t]{2}{*}{$\begin{array}{l}\text { Geographical } \\
\text { location }\end{array}$} & \multirow[t]{2}{*}{ Population } & \multirow[t]{2}{*}{ Regimen } & \multicolumn{2}{|l|}{$\begin{array}{l}\text { Any detectable plasma } \\
\text { drug (TDF or FTC) (\%) }\end{array}$} & \multirow[t]{2}{*}{ Self-report (\%) } & \multirow[t]{2}{*}{ Pill count (\%) } & \multirow[t]{2}{*}{ MEMS (\%) } \\
\hline & & & & & $\begin{array}{l}\text { HIV - } \\
\text { (non-seroconverters) }\end{array}$ & $\begin{array}{l}\text { HIV + } \\
\text { (seroconverters) }\end{array}$ & & & \\
\hline 2010 & iPrEx [6] & Global & MSM/TGW & Daily & 51 & 9 & 95 & $>90$ & - \\
\hline 2012 & $\begin{array}{l}\text { Partners } \\
\text { study [7] }\end{array}$ & $\begin{array}{l}\text { Kenya and } \\
\text { Uganda }\end{array}$ & $\begin{array}{l}\text { Heterosexual } \\
\text { HIV-discordant } \\
\text { couples }\end{array}$ & Daily & 82 & 31 & - & 92 & - \\
\hline 2012 & TDF2 [8] & Botswana & Heterosexual & Daily & 80 & 50 & 94 & 84 & - \\
\hline 2012 & $\begin{array}{l}\text { FEM-PrEP } \\
{[13]}\end{array}$ & $\begin{array}{l}\text { Kenya, } \\
\text { Tanzania, } \\
\text { South Africa }\end{array}$ & $\begin{array}{l}\text { Heterosexual } \\
\text { females }\end{array}$ & Daily & 24 & 15 & 95 & 88 & - \\
\hline \multirow[t]{2}{*}{2012} & \multirow{2}{*}{$\begin{array}{l}\text { Kenya safety } \\
\text { and adherence } \\
\text { study [38] }\end{array}$} & \multirow[t]{2}{*}{ Kenya } & \multirow{2}{*}{$\begin{array}{l}\text { MSM and } \\
\text { female sex } \\
\text { workers }\end{array}$} & Daily & \multirow[t]{2}{*}{-} & \multirow[t]{2}{*}{-} & - & \multirow[t]{2}{*}{-} & $\begin{array}{l}83 \% \\
\text { (IQR } 63 \text { to } 92)\end{array}$ \\
\hline & & & & Time-driven & & & 100 & & $\begin{array}{l}55 \\
\text { (pre-coital), } \\
26 \text { (post-coital) }\end{array}$ \\
\hline 2013 & $\begin{array}{l}\text { Partners } \\
\text { adherence } \\
\text { substudy [17] }\end{array}$ & $\begin{array}{l}\text { Kenya and } \\
\text { Uganda }\end{array}$ & $\begin{array}{l}\text { Heterosexual } \\
\text { HIV-discordant } \\
\text { couples }\end{array}$ & Daily & - & - & - & 99 & 97 \\
\hline 2013 & $\begin{array}{l}\text { Bangkok } \\
\text { tenofovir } \\
\text { study [31] }\end{array}$ & Bangkok & PWID & Daily & 67 & 39 & 94 & - & - \\
\hline \multirow[t]{2}{*}{2013} & \multirow{2}{*}{$\begin{array}{l}\text { Uganda safety } \\
\text { and adherence } \\
\text { study [35] }\end{array}$} & \multirow[t]{2}{*}{ Uganda } & \multirow{2}{*}{$\begin{array}{l}\text { Heterosexual } \\
\text { HIV-discordant } \\
\text { couples }\end{array}$} & Daily & \multirow[t]{2}{*}{ - } & & - & \multirow[t]{2}{*}{-} & 97 \\
\hline & & & & Time-driven & & & 100 & & $\begin{array}{l}91 \text { (pre-coital) } 45 \\
\text { (post-coital) }\end{array}$ \\
\hline 2013 & $\begin{array}{l}\text { ATN } 082 \\
\text { (Project } \\
\text { PrEPARE) } \\
{[54]}\end{array}$ & United States & Young MSM & Daily & 20 & & 62 & - & - \\
\hline 2014 & $\begin{array}{l}\text { iPrEx } \\
\text { extension } \\
{[15]}\end{array}$ & Global & MSM/TGW & Daily & 71 & & $85^{c}$ & - & - \\
\hline \multirow[t]{2}{*}{2015} & \multirow[t]{2}{*}{ VOICE [14] } & \multirow[t]{2}{*}{$\begin{array}{l}\text { South Africa, } \\
\text { Uganda, } \\
\text { Zimbabwe }\end{array}$} & \multirow[t]{2}{*}{$\begin{array}{l}\text { Heterosexual } \\
\text { females }\end{array}$} & Daily & \multirow{2}{*}{\multicolumn{2}{|c|}{ 29supp }} & $\begin{array}{l}87 \\
\text { (via computer), } \\
90 \\
\text { (face to face) }\end{array}$ & 88 & \multirow[t]{2}{*}{-} \\
\hline & & & & & & & $\begin{array}{l}87 \text { (via computer), } \\
91 \text { (face to face) }\end{array}$ & 84 & \\
\hline 2015 & $\begin{array}{l}\text { Generating } \\
\text { adherence } \\
\text { Philadelphia } \\
\text { [50] }\end{array}$ & United States & $\begin{array}{l}\text { Young MSM } \\
\text { of colour }\end{array}$ & Daily & - & & - & 72 & - \\
\hline \multirow[t]{3}{*}{2015} & HPTN 067/ & South Africa & Heterosexual & Daily & 68 & & - & - & 76 \\
\hline & [36] & & & Time-driven & 56 & & & & 65 \\
\hline & & & & $\begin{array}{l}\text { Event- } \\
\text { driven }\end{array}$ & 53 & & & & 53 \\
\hline 2015 & PROUD [9] & $\begin{array}{l}\text { United } \\
\text { Kingdom }\end{array}$ & MSM & Daily & $100^{c}$ & & - & - & - \\
\hline 2015 & IPERGAY [10] & $\begin{array}{l}\text { France and } \\
\text { Canada }\end{array}$ & MSM/TGW & $\begin{array}{l}\text { Event- } \\
\text { driven }\end{array}$ & 87 & 0 & $\begin{array}{l}29 \\
\text { (suboptimal), } \\
43 \text { (optimal) }\end{array}$ & - & - \\
\hline 2016 & $\begin{array}{l}\text { Bangkok } \\
\text { MSM }^{\mathrm{a}}[55]\end{array}$ & Thailand & MSM/TGW & Daily & - & & $\begin{array}{l}9.8 \\
\text { (complete adherence) }\end{array}$ & - & - \\
\hline 2016 & $\begin{array}{l}\text { Permanente } \\
\text { Cohort [24] }\end{array}$ & USA & At-risk & Daily & - & & - & 92 & - \\
\hline 2016 & $\begin{array}{l}\text { The Demo } \\
\text { Project [23] }\end{array}$ & USA & MSM/TGW & Daily & $80^{d}$ & & - & 82 & - \\
\hline 2017 & SPARK $^{\mathrm{a}}$ [57] & United States & MSM & Daily & 90 & & - & - & - \\
\hline
\end{tabular}


Table 2 Adherence to oral PrEP by different measures used (Continued)

\begin{tabular}{|c|c|c|c|c|c|c|c|c|c|}
\hline \multicolumn{5}{|c|}{ Characteristics } & \multicolumn{5}{|l|}{ Adherence } \\
\hline \multirow[t]{2}{*}{ Year } & \multirow[t]{2}{*}{ Study name } & \multirow[t]{2}{*}{$\begin{array}{l}\text { Geographical } \\
\text { location }\end{array}$} & \multirow[t]{2}{*}{ Population } & \multirow[t]{2}{*}{ Regimen } & \multicolumn{2}{|l|}{$\begin{array}{l}\text { Any detectable plasma } \\
\text { drug (TDF or FTC) (\%) }\end{array}$} & \multirow[t]{2}{*}{ Self-report (\%) } & \multirow[t]{2}{*}{ Pill count (\%) } & \multirow[t]{2}{*}{ MEMS $(\%$} \\
\hline & & & & & $\begin{array}{l}\text { HIV - } \\
\text { (non-seroconverters) }\end{array}$ & $\begin{array}{l}\text { HIV + } \\
\text { (seroconverters) }\end{array}$ & & & \\
\hline 2017 & $\begin{array}{l}\text { IPERGAY } \\
\text { extension } \\
{[22]}\end{array}$ & $\begin{array}{l}\text { France/ } \\
\text { Canada }\end{array}$ & MSM/TGW & $\begin{array}{l}\text { Event- } \\
\text { driven }\end{array}$ & $71^{e}$ & 0 & $\begin{array}{l}24 \text { (suboptimal), } \\
50 \text { (optimal) }\end{array}$ & - & - \\
\hline 2017 & $\begin{array}{l}\text { Short term } \\
\text { PrEP } \\
\text { Mozambique } \\
{[25]}\end{array}$ & Mozambique & $\begin{array}{l}\text { Heterosexual } \\
\text { females }\end{array}$ & Daily & 76 & & & & - \\
\hline 2017 & $\begin{array}{l}\text { Parisian } \\
\text { MSM }^{\mathrm{a}}[26]\end{array}$ & France & MSM & $\begin{array}{l}\text { Daily \& } \\
\text { Event- } \\
\text { driven }\end{array}$ & 83 & & - & - & - \\
\hline 2017 & $\begin{array}{l}\text { PRELUDE } \\
{[27,28]}\end{array}$ & Australia & $\begin{array}{l}\text { Gay/bisexual } \\
\text { males }\end{array}$ & Daily & $51^{d}$ & & - & - & - \\
\hline 2017 & $\begin{array}{l}\text { PROUD } \\
\text { adherence }^{\text {a }} \\
\text { [29] }\end{array}$ & UK & MSM & Daily & - & & 98 & - & - \\
\hline 2017 & Pluspills ${ }^{a}[30]$ & South Africa & Adolescents & Daily & 38 & & - & 92 & - \\
\hline 2017 & $\begin{array}{l}\text { Brazil } \\
\text { Demo }^{a}[65]\end{array}$ & Brasil & MSM/TGW & Daily & 74 & & - & - & - \\
\hline
\end{tabular}

${ }^{a}$ Abstract available only, ${ }^{b}$ At most recent sexual encounter, ${ }^{c}$ Of participants reporting good adherence, ${ }^{d}$ Dried blood spot concentration,

${ }^{e}$ Only $33 \%$ of participants had plasma TDF concentrations consistent with taking $>4$ tablets per week

infected post-randomisation (M184 V mutation), all in the trial arm. The 2012 TDF2 trial reported the K65R, $\mathrm{M} 184 \mathrm{~V}$, and $\mathrm{A} 62 \mathrm{~V}$ mutations in 1 of 10 trial-arm participants infected with HIV. That individual had an unrecognised HIV infection at baseline. The PROUD trial reported FTC resistance in 2 individuals assigned to the immediate arm who were infected with HIV at baseline or 4 -weeks $(66.6 \%)$, but no resistance in either of the 2 participants infected later on. Only 2 cases of resistance have been reported in HIV infected individuals assigned to placebo/comparator groups.

\section{Discussion}

\section{Efficacy and effectiveness}

This review discusses adherence to oral PrEP in the context of efficacy data from previous studies. We found that oral TDF and TDF-FTC PrEP for the prevention of HIV in humans is efficacious and effective in a variety of scenarios. Two recent trials within MSM populations in the UK and France/Canada report $86 \%$ effectiveness (90\% CI, 64 to 96\%) [9], and $86 \%$ efficacy (95\% CI, 40 to $98 \%$ ) [10] in daily and event-driven regimens respectively. Additionally, PrEP

Table 3 Modified Intention to Treat efficacy and effectiveness of studies examining oral PrEP

\begin{tabular}{|c|c|c|c|c|c|}
\hline \multicolumn{5}{|c|}{ Characteristics } & \multirow{2}{*}{$\begin{array}{l}\text { Outcome } \\
\text { Efficacy }(\%, 95 \mathrm{Cl})\end{array}$} \\
\hline Year & Study name & Population & Regimen & Drug & \\
\hline 2010 & iPrEx [6] & MSM/TGW & Daily & TDF-FTC & $44 \%$ (15 to 63 ) \\
\hline \multirow[t]{2}{*}{2012} & \multirow[t]{2}{*}{ Partners study [7] } & \multirow{2}{*}{$\begin{array}{l}\text { Heterosexual HIV-discordant } \\
\text { couples }\end{array}$} & \multirow[t]{2}{*}{ Daily } & TDF-FTC & $75 \%$ (55 to 87 ) \\
\hline & & & & TDF & $67 \%$ (44 to 81$)$ \\
\hline 2012 & TDF2 [8] & Heterosexual & Daily & FTC- TDF & $62.2 \%(21.5$ to 83.4$)$ \\
\hline 2012 & FEM-PrEP [13] & Heterosexual Females & Daily & TDF-FTC & $6 \%(-52$ to $41 \%)$ \\
\hline 2013 & Bangkok tenofovir study [31] & PWID & Daily & TDF & $48.9 \%$ (9.6 to 72.2 ) \\
\hline 2014 & iPrEx extension [15] & MSM/TGW & Daily & TDF-FTC & $36 \%(-24 \text { to } 67)^{a}$ \\
\hline \multirow[t]{2}{*}{2015} & \multirow[t]{2}{*}{ VOICE [14] } & \multirow[t]{2}{*}{ Heterosexual Females } & \multirow[t]{2}{*}{ Daily } & TDF-FTC & $-4 \%(-49$ to 27$)$ \\
\hline & & & & TDF & $-49 \%(-129$ to 3$)$ \\
\hline 2015 & PROUD [9] & MSM & Daily & TDF-FTC & $86 \%(90 \%$ Cl 64 to 96$)$ \\
\hline 2015 & IPERGAY [10] & MSM/TGW & Event-driven & TDF-FTC & $86 \%$ (40 to 98$)$ \\
\hline
\end{tabular}

a Unknown if intention to treat or modified intention to treat. MSM men who have sex with men, TGW transgender women, PWID people who inject drugs, TDF tenofovir, FTC emtricitabine 


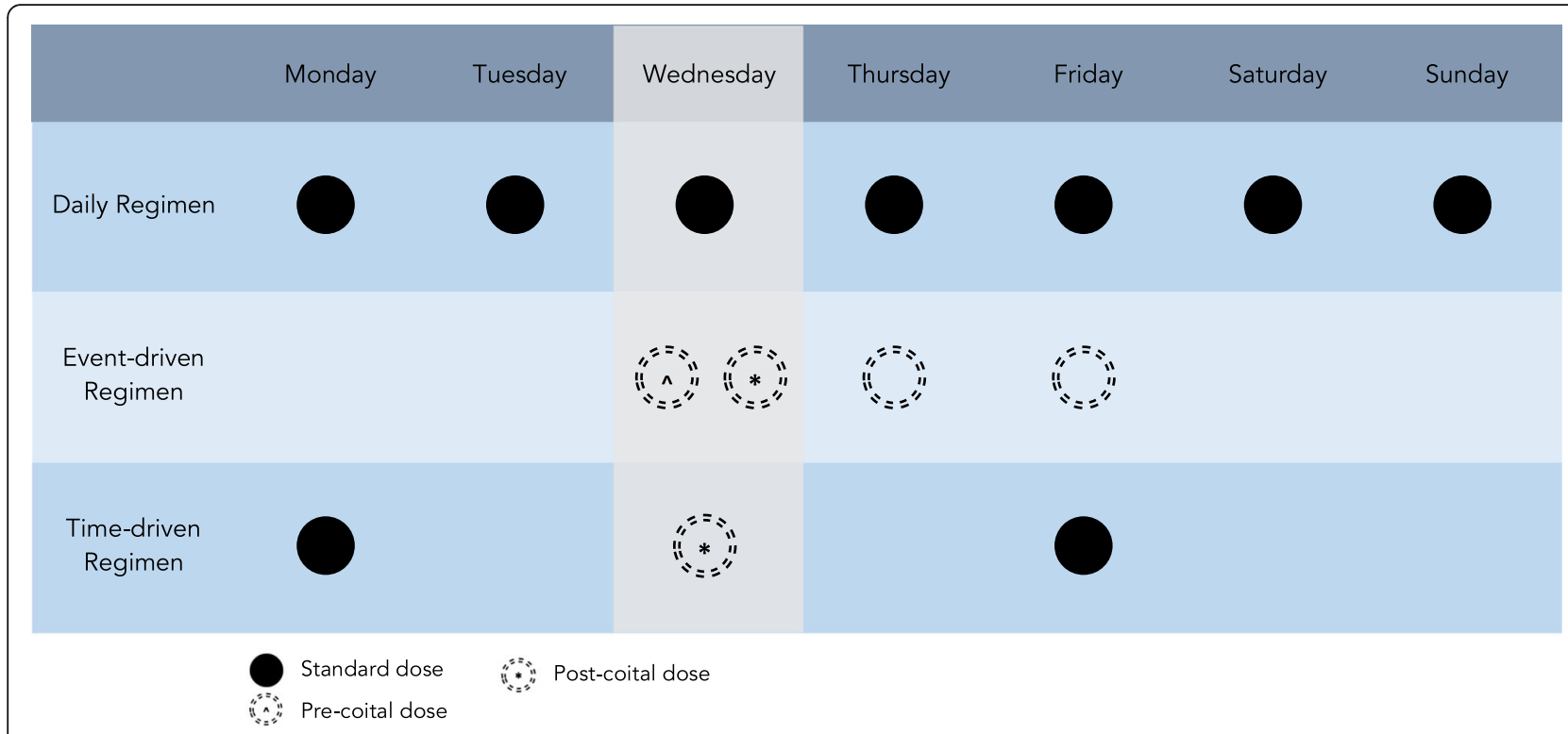

Fig. 2 Chart depicting available currently available oral PrEP dosing regimens. The pale column represents a possible HIV exposure event

is efficacious in serodiscordant heterosexual couples [7] (efficacy 75\%; 95\% CI, 55 to 87\%).

However, two large trials in heterosexual women failed to demonstrate efficacy [13, 14]. Whilst adherence was low in both studies, as inferred from plasma drug levels, concerns have been previously raised regarding the differential distribution of antiretroviral (ARV) components within rectal and cervical mucosae [20]. Rectal tissue concentrations of TDF are two orders of magnitude greater than in cervical tissue at the same dose, suggesting that equal dosing for men and women may result in insufficient mucosal concentrations to prevent HIV infection in females. Atypical vaginal microbiota have been proposed to decrease the effectiveness of PrEP and increase the risk of HIV acquisition, possibly by increasing ARV metabolism or by weakening the cervicovaginal barrier [39]. However, a post-hoc analysis of the Partners study found that oral PrEP was equally efficacious among woman with bacterial vaginosis as without, and furthermore was not significantly different with the detection of G. vaginalis or Bacteroides spp. morphotypes [40]. This suggests that oral PrEP formulations do not require testing for bacterial vaginosis or treatment to ensure protection from HIV acquisition.

\section{Adherence}

Adherence to oral PrEP varies greatly between trials and study populations. We found that adherence was consistently high when measured via self-report, pill count and electronic methods, but generally lower when assessed via plasma drug concentrations of TDF and/or FTC. Furthermore, 'detectable plasma TDF' rates are frequently reported, however the lower limit of plasma drug detection corresponds to fewer than two pills per week (very poor adherence), making interpretation challenging. While many participants over-report adherence to PrEP, it is unclear whether this is intentional or not. This may be due to social desirability bias as participants in the trials frequently receive adherence counselling, and therefore are well aware of the importance of compliance to PrEP. Comparison of adherence between trials is further complicated by the large variety of adherence measures available, with different methods used within measures themselves. For example, self-report methodology varies from daily SMS reports to monthly interviews, whilst pill count methodology includes unannounced home visits, MEMS, and pharmacy counts amongst other strategies. Therefore, comparability is limited between studies and study populations.

Table 4 Cases of resistance have been reported in several oral PrEP studies

\begin{tabular}{|c|c|c|c|c|c|c|}
\hline \multirow[t]{2}{*}{ Study Name } & \multicolumn{3}{|l|}{ Trial arm } & \multicolumn{3}{|c|}{ Placebo/comparator arm } \\
\hline & Total HIV infections & Cases of resistance & $\%$ & Total HIV infections & Cases of resistance & $\%$ \\
\hline Fem-PrEP [13] & 34 & 4 & 11.7 & 39 & 1 & 2.56 \\
\hline TDF2 [8] & 10 & 1 & 10 & 26 & 1 & 3.85 \\
\hline VOICE (TDF-FTC arm) [14] & 61 & 3 & 4.92 & & & 0 \\
\hline PROUD [9] & 5 & 2 & 40 & 0 & 0 & 0 \\
\hline
\end{tabular}


Promisingly, a succession of recent papers and conference abstracts report high levels of real-world adherence [22-24]. One open label intervention of daily PrEP found $80 \%$ of participants had protective plasma drug levels at 48 weeks [23], and an open label investigation of event-driven PrEP yielded detectable plasma drug levels in $71 \%$ of participants at 6 months [22]. However, Computer Assisted Structured Interviews determined that on-demand PrEP was only used at the correct dose in $50 \%$ of sexual intercourses. Whilst interviews may suffer from self-report and recall bias, one might expect adherence to be overestimated, rather than underestimated, due to social desirability bias. Although there is currently insufficient data to justly compare on-demand and daily regimens, this disparity should be noted for further investigation.

\section{Reasons for non-adherence}

The reasons reported for non-adherence (Fig. 3) are broad, reflecting the wide variety of populations and settings in which trials have been performed. Common qualitative reasons for poor adherence included participant low risk perception, side-effects, perceived stigma and dosing regimen incompatibility. These findings are consistent with reports from individual trials, which note that start-up side effects are frequent $[6,8]$ and may have influenced adherence. However, the Bangkok Tenofovir Study reported that nausea and vomiting were start-up symptoms which abated after the first couple of months [31]. However, of trials reporting dosing regimen as a reason for low adherence, three used a daily regimen and two used an on-demand regimen, implying limited acceptability regardless of daily or on-demand dosing regimen. However, comparatively little research has been performed using on-demand regimens, therefore further research is required to explore the differences in acceptability between daily and on-demand regimen. Recent modelling suggests weekly oral dosing with controlled release formulations may lead to improved adherence [41], implying that long-acting PrEP formulations may provide some solutions to poor acceptability of current dosing regimens.

\section{Stigma}

"Stigma remains the single most important barrier to public action [against HIV]", wrote ex-UN Secretary General Ban Kai-Moon in 2008 [42]. This statement is unfortunately still just as relevant in both low- and high-income settings, and has important implications for PrEP initiatives worldwide [43]. Qualitative investigation of PrEP trials has elicited both social and self-stigmatisation as instrumental challenges for participant adherence. Interviews with participants from the failed VOICE trial found that it was important for women from South Africa,
Zimbabwe and Uganda to be perceived as healthy by the community [44]. Taking medication associated with being HIV positive did not align with their narrative of health through self-stigmatisation, which may have detrimentally affected adherence. Furthermore, participants were understandably concerned that community misunderstanding regarding PrEP could cause friends and family to believe that they were HIV positive [45]. Some participants resorted to hiding the medication and pill bottles, however the conspicuous physical characteristics of the tablet were hard to explain. In the most severe cases, participants experienced extreme reactions from their close family, even resulting in spouse or partner separation $[44,45]$.

\section{Risk perception and knowledge}

Low risk perception is a common issue within PrEP trials. Despite adherence counselling, a large proportion of women $(>70 \%)$ from Kenya, Tanzania and South Africa reported themselves as at low or no risk of HIV in the failed FEM-PrEP trial [13]. Low risk perception was also a common reason for MSM declining PrEP in the United States PrEPARE trial [32], despite all eligible individuals belonging to a population at actual high risk. Reasons for low risk perception are unclear, although may relate to generally poor HIV education, which is often neglected in sex education [46-48]. PrEP will need to be delivered within a comprehensive package, including regular HIV awareness and PrEP adherence counselling if sufficient adherence for success is to be maintained.

\section{Decision making power}

PrEP is often prescribed to individuals who live in difficult circumstances. MSM, transgender, sex worker and PWID populations carry burdens of HIV disproportional to their size, and are at risk of being left behind in HIV prevention [49]. Stigma and criminalisation further marginalises these groups in many countries $[3,4]$. The prospect of social ostracism and prosecution introduces further structural barriers to accessing healthcare services, reducing PrEP uptake and adherence. In a study of young MSM of colour in the USA, 39\% had been kicked out of their home due to their sexual orientation and $43 \%$ had spent at least one night on the street [50]. These factors, combined with the prevalence of transactional sex, mean that young women and MSM, particularly transgender women, are often subject to abuse $[5,50]$ and frequently lack decision-making power over their bodies when it comes to sexual encounters [51]. These structural and social barriers, which reduce agency, can generate considerable difficulty in maintaining sufficient adherence to the dosing regimen and in accessing health services [3]. Despite this data previous trials within MSM populations have been surprisingly successful compared with young heterosexual women. This review cannot resolve this difference, but considering gender perspectives 


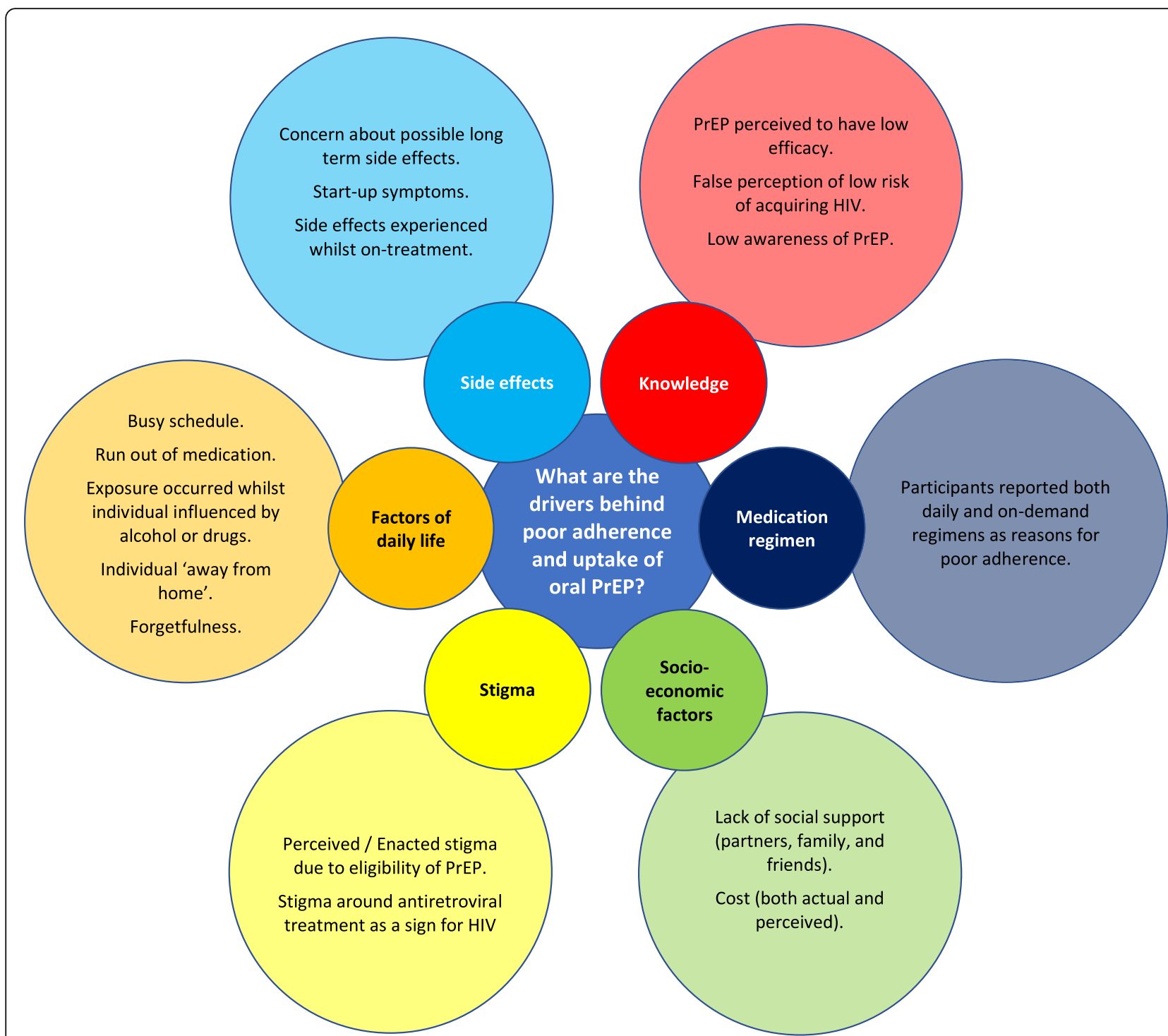

Fig. 3 Grouped reasons reported for poor adherence to oral PrEP that were found in studies included in this article, and for high risk individuals declining medication

within differing populations may offer some insight, particularly by considering the relation of cultural gender roles to decision-making power.

\section{Drug resistance}

With poor adherence a frequent issue in PrEP users, the question of drug resistance is of elevated concern. A full review of drug resistance in PrEP lies beyond this review, but most published RCTs report drug resistance as a rare outcome. Due to the rarity of resistance, it is also currently difficult to quantify the risk. However, it does appear to be more frequent among individuals receiving PrEP.

The infection of individuals between enrolment and randomisation $[7,9,14]$, or missed diagnoses of pre-existing HIV infection [8], meant that these participants were likely exposed to high drug concentrations whilst in the acute phase of HIV infection. This was, however, very rare in the RCTs. As HIV serology assays that are often used cannot detect HIV infection during the acute phase, this remains a challenge for PrEP programmes in low income settings. HIV-RNA detection can be performed at enrolment to ensure that PrEP is not prescribed to any individual who recently acquired HIV, which may be cost effective and even cost-saving in higher prevalence populations [52]. Regardless, it is difficult to know whether mutations are due to prescribed medication, or due to previous exposure without healthcare worker consultation. We also note an MSM individual who was fully adherent to TDF-FTC PrEP was recently reported to have been infected with a resistant strain of HIV 
[53]. This provided the first compelling evidence of breakthrough infection despite good adherence to oral PrEP by drug-resistant HIV-1.

From this data, it seems that PrEP is not associated with a large risk of drug-resistance developing. The low drug plasma concentrations associated with poor adherence appear to confer a low risk of resistance should HIV infection occur, whilst high plasma concentrations in adherent individuals make resistance development unlikely through successful inhibition of viral replication. However, with wide scale PrEP use around the corner, resistance may soon become a greater issue, especially in developing countries where follow-up and routine monitoring is more difficult. Furthermore, infection by resistant strains remains a rare possibility and individuals who are infected with HIV whilst truly adherent to PrEP may propagate resistant strains. Thorough disease history and clinical examination could help to detect acute phase HIV. When acute phase HIV is suspected, PrEP can be delayed to ensure a reliable negative HIV serology before initiation or HIV-RNA analysis can be performed in settings where this is available. Reasonable care should be taken to ensure participants are not infected with HIV prior to PrEP initiation.

\section{Challenges in clinical practice}

Current knowledge relating to oral PrEP suffers from knowledge gaps. There are few long-term studies relating to effectiveness and adherence, and while some trials report that adherence is stable over time [15], others suggest a long-term decline $[17,18,54]$. This is particularly important for oral PrEP due the importance of good adherence for its protective effect. It is often challenging to trace and maintain interaction with populations most at risk of HIV acquisition. This is critical for the success of PrEP due to the necessity of regular pill distribution and HIV/STI testing. To further complicate matters, a recent study in Bangkok found little association between participants intending to take PrEP and actual adherence at 1 month [55]. It is important to demonstrate that PrEP adherence can be maintained in key populations over time for it to be effective.

Effective methods of encouraging adherence are likely to be as varied as the populations themselves. Success was reported in a US community based programme [50] through four key strategies. First, PrEP was delivered as a key component within a comprehensive prevention package, from a place often visited by the population (e.g. young MSM). Secondly, high contact frequency (weekly) was maintained. Thirdly, the package promoted all aspects of a healthy lifestyle., and finally aimed to further empower individuals through optional weekly workshops focussing on life-skills. Linked with a comprehensive strategy, peer navigators, who aim to solve individual barriers to PrEP, are being evaluated as an option to maintain adherence and retention [56]. One recent study (SPARK) also found high adherence rates at 3 months in conjunction with a comprehensive sexual health intervention, supporting the feasibility of incorporating PrEP adherence counselling into existing frameworks [57].

This promising model could feasibly be adapted for use in other populations. Multi-modal intervention models are effective in maintaining medication adherence for other conditions, but it is recommended that programmes are designed to allow evaluation of individual components [58]. There is already evidence that text messaging is highly acceptable and may improve retention in PrEP programs [59]. Smartphone penetration is also high in many countries, such as the UK where $91 \%$ of 18 to 34 year olds own a device [60], and Sub-Saharan Africa where penetrance is expected to exceed $50 \%$ by 2020 [61]. This could present an opportunity for innovative adherence solutions. Apps could be designed to display medication reminders, allow adherence self-reporting, and even to incentivise good adherence through reward.

The increasing online availability of generic PrEP, which is accessed and used by individuals without a doctor's prescription and without proper prior HIV screening, presents a real challenge. If the user cost of accessing PrEP on prescription exceeds the cost of purchasing generic versions online, then individuals are likely to take PrEP acquisition into their own hands. In France, the first and only European country to offer PrEP through public health services, over $60 \%$ of on-PrEP MSM access medication via their physician as opposed to less than $30 \%$ in other countries [62]. Correspondingly, less than 10\% of on-PrEP French MSM access medication online as opposed to over $40 \%$ in other European countries [62]. Unmonitored PrEP usage could result in risk to users from adverse effects due to excessive dosing, and HIV infection due to insufficient dosing, whilst simultaneously accelerating the development of resistance if new infections are undiagnosed. It may also present a public health risk if high-risk individuals using unmonitored PrEP perceive themselves at lower risk of HIV, and subsequently do not attend HIV testing services as frequently. However, 31 European countries still identify cost of medication and service delivery as a major barrier to PrEP implementation, despite this unique opportunity to target HIV transmission in the most high-risk groups [62]. Despite this, recent modelling research in the UK suggests cost-effectiveness and long term cost-saving benefits across a wide range of PrEP introduction scenarios for the MSM population [63]. Cost savings depended on both the eligible population and the risk of HIV acquisition, so long term cost-effectiveness is likely to be even greater in locations 
with higher HIV prevalence. Notably, cost-effectiveness was highly time sensitive, suggesting that policy makers must consider PrEP over lifetimes, and not merely the political cycle.

\section{Limitations}

Despite best efforts to ensure a comprehensive search, there may be eligible studies that we failed to include. We made efforts to contact authors of soon to be released trials, but not all authors were contactable. Secondly, the conclusions we draw are only as good as the data provided. There is reason for concern over the use of pill counts and current electronic monitoring methods as measures of PrEP adherence due to the varying concordance with blood plasma drug concentrations. Furthermore, this review is limited to discussion of oral PrEP adherence in the context of efficacy. Long-term safety, cost effectiveness, HIV drug resistance and sexual behaviour trends are not evaluated or discussed in detail. Finally, whilst this paper discussed adherence in detail, it must be noted that adherence is just one step in the broader PrEP retention continuum [16].

\section{Conclusions}

Oral PrEP can be effective for the prevention of HIV. Some interventions have achieved high adherence and clinical effectiveness among MSM. However, further exploration of the biological and sociocultural reasons for poor adherence in other populations such as women is required. Cheap and accurate methods of long term adherence monitoring, such as urine testing, require development and validation. Interventions must be designed with user-appropriateness in mind, considering the sometimes unpredictable lives of at-risk individuals at the fringe of society in addition to those in the centre. Flexible medication delivery models and extended release PrEP formulations will likely play an important role in catering to these needs, and further research will be needed to design and prove these methods. Moreover, efforts should be taken to challenge the stigma, marginalisation and prosecution of minority groups, such as sex workers, PWID, and MSM, both within the community and at governmental level. Drug resistance to PrEP is still rare, but sufficient data to fully quantify the risk of resistance is likely to only be available once widespread use in lower income settings and at larger scale is achieved. Finally, the cost-issues for using preventive ARVs must be dealt with at national level in many countries.

\footnotetext{
Abbreviations

ART: Antiretroviral Therapy; ARV: Antiretroviral; CDC: Centres for Disease prevention and Control; FTC: Emtricitabine; MEMS: Medication Event Monitoring System; MSM: Men who have Sex with Men; PrEP: Pre-Exposure Prophylaxis; PWID: People Who Inject Drugs; RCT: Randomised Controlled Trial; RDBPCT: Randomised Double Blind Placebo Controlled Trial; TDF: Tenofovir disoproxil fumarate; TGW: Transgender Women; UN: United Nations; WHO: World Health Organisation
}

\section{Acknowledgements}

The authors thank the participants in the individual studies included in this systematic review for their contribution to evidence for PrEP.

\section{Funding}

DS provided support for this article in kind. AME was funded by Karolinska Institutet. SS was funded by Uppsala University. Funding institutions had no role in designing the review, the collection, analysis, or interpretation of the data, nor the writing of the manuscript.

\section{Availability of data and materials}

Not applicable for this systematic review; all articles included are publicly available.

\section{Authors' contributions}

All authors made significant contributions to the design of the review. DS and SS performed the systematic search. DS performed data extraction; DS SS, and AME jointly performed analysis and interpretation. DS, SS and AME all contributed to writing the manuscript. All authors approved the

manuscript and submission and agree to be accountable for the content.

\section{Authors' information}

Not applicable.

Ethics approval and consent to participate

Not Applicable.

\section{Consent for publication}

Not applicable.

\section{Competing interests}

The authors declare that they have no competing interests.

\section{Publisher's Note}

Springer Nature remains neutral with regard to jurisdictional claims in published maps and institutional affiliations.

\section{Author details}

'Department of Public Health Sciences, Karolinska Institutet, Stockholm, Sweden. ${ }^{2}$ Department of Medical Sciences, Section of Infectious Diseases, Uppsala University, Uppsala, Sweden. ${ }^{3}$ Department of Infectious Diseases, Karolinska University Hospital, Stockholm, Sweden.

Received: 11 January 2018 Accepted: 31 October 2018

Published online: 16 November 2018

\section{References}

1. UNAIDS. Global AIDS Update 2016. Geneva: UNAIDS; 2016.

2. Cohen MS, Chen YQ, McCauley M, Gamble T, Hosseinipour MC, Kumarasamy N, Hakim JG, Kumwenda J, Grinsztejn B, Pilotto JH, et al. Prevention of HIV-1 infection with early antiretroviral therapy. N Engl I Med. 2011;365(6):493-505

3. Joint United Nations Programme on HIV/AIDS. Prevention Gap Report. Geneva: Joint United Nations Programme on HIV/AIDS; 2016.

4. Carroll A. State sponsored homophobia 2016: a world survey of sexual orientation laws: criminalisation, protection and recognition. 11th ed. Geneva: International Lesbian, Gay, Bisexual, Trans and Intersex Association; 2016.

5. Baral SD, Poteat T, Strömdahl S, Wirtz AL, Guadamuz TE, Beyrer C. Worldwide burden of HIV in transgender women: a systematic review and meta-analysis. Lancet Infect Dis. 2013;13(3):214-22.

6. Grant RM, Lama JR, Anderson PL, McMahan V, Liu AY, Vargas L, Goicochea P, Casapía M, Guanira-Carranza JV, Ramirez-Cardich ME, et al. Preexposure chemoprophylaxis for HIV prevention in men who have sex with men. $\mathrm{N}$ Engl J Med. 2010;363(27):2587-99.

7. Baeten JM, Donnell D, Ndase P, Mugo NR, Campbell JD, Wangisi J, Tappero JW, Bukusi EA, Cohen CR, Katabira E, et al. Antiretroviral prophylaxis for HIV prevention in heterosexual men and women. N Engl J Med. 2012;367(5): 399-410.

8. Thigpen MC, Kebaabetswe PM, Paxton LA, Smith DK, Rose CE, Segolodi TM, Henderson FL, Pathak SR, Soud FA, Chillag KL, et al. Antiretroviral preexposure prophylaxis for heterosexual HIV transmission in Botswana. N Engl J Med. 2012;367(5):423-34. 
9. McCormack S, Dunn DT, Desai M, Dolling DI, Gafos M, Gilson R, Sullivan AK, Clarke A, Reeves I, Schembri G, et al. Pre-exposure prophylaxis to prevent the acquisition of HIV-1 infection (PROUD): effectiveness results from the pilot phase of a pragmatic open-label randomised trial. Lancet. 2016; 387(10013):53-60.

10. Molina JM, Capitant C, Spire B, Pialoux G, Cotte L, Charreau I, Tremblay C, Le Gall JM, Cua E, Pasquet A, et al. On-demand Preexposure prophylaxis in men at high risk for HIV-1 infection. N Engl J Med. 2015;373(23):2237-46.

11. Consolidated guidelines on the use of antiretroviral drugs for treating and preventing HIV infection. Recommendations for a public health approach. 2nd ed. France: World Health Organization; 2016.

12. Centers for Disease Control and Prevention. Preexposure Prophylaxis for the Prevention of HIV Infection in the United States - 2014 Clinical Practice Guideline. Atlanta: Centers for Disease Control and Prevention; 2014

13. Van Damme L, Corneli A, Ahmed K, Agot K, Lombaard J, Kapiga S, Malahleha M, Owino F, Manongi R, Onyango J, et al. Preexposure prophylaxis for HIV infection among African women. N Engl J Med. 2012; 367(5):411-22.

14. Marrazzo JM, Ramjee G, Richardson BA, Gomez K, Mgodi N, Nair G, Palanee T, Nakabiito C, van der Straten A, Noguchi L, et al. Tenofovir-based preexposure prophylaxis for HIV infection among African women. N Engl J Med. 2015;372(6):509-18.

15. Grant RM, Anderson PL, McMahan V, Liu A, Amico KR, Mehrotra M, Hosek S, Mosquera C, Casapia M, Montoya O, et al. Uptake of pre-exposure prophylaxis, sexual practices, and HIV incidence in men and transgender women who have sex with men: a cohort study. Lancet Infect Dis. 2014 14(9):820-9.

16. Nunn AS, Brinkley-Rubinstein L, Oldenburg CE, Mayer KH, Mimiaga M, Pate R, Chan PA. Defining the HIV pre-exposure prophylaxis care continuum. AIDS. 2017:31(5):731-4

17. Haberer JE, Baeten JM, Campbell J, Wangisi J, Katabira E, Ronald A, Tumwesigye E, Psaros C, Safren SA, Ware NC, et al. Adherence to antiretroviral prophylaxis for HIV prevention: a substudy cohort within a clinical trial of serodiscordant couples in East Africa. PLoS Med. 2013;10(9):e1001511.

18. Baeten JM, Donnell D, Mugo NR, Ndase P, Thomas KK, Campbell JD, Wangisi J, Tappero JW, Bukusi EA, Cohen CR, et al. Single-agent tenofovir versus combination emtricitabine plus tenofovir for pre-exposure prophylaxis for HIV-1 acquisition: an update of data from a randomised, double-blind, phase 3 trial. Lancet Infect Dis. 2014;14(11):1055-64.

19. (CASP) CASP. Randomised Controlled Trials Checklist. Oxford: Critical Appraisal Skills Programme; 2013.

20. Patterson KB, Prince HA, Kraft E, Jenkins AJ, Shaheen NJ, Rooney JF, Cohen MS, Kashuba AD. Penetration of tenofovir and emtricitabine in mucosal tissues: implications for prevention of HIV-1 transmission. Sci Transl Med. 2011;3(112):112re114.

21. Anderson PL, Liu AY, Castillo-Mancilla JR, Gardner EM, Seifert SM, McHugh C, Wagner T, Campbell K, Morrow M, Ibrahim M, et al. Intracellular Tenofovirdiphosphate and Emtricitabine-triphosphate in dried blood spots following directly observed therapy. Antimicrob Agents Chemother. 2018;62(1):e01710-17.

22. Molina JM, Charreau I, Spire B, Cotte L, Chas J, Capitant C, Tremblay C, Rojas-Castro D, Cua E, Pasquet A, et al. Efficacy, safety, and effect on sexual behaviour of on-demand pre-exposure prophylaxis for HIV in men who have sex with men: an observational cohort study. Lancet HIV. 2017;4(9):e402-10.

23. Liu AY, Cohen SE, Vittinghoff E, Anderson PL, Doblecki-Lewis S, Bacon O, Chege W, Postle BS, Matheson T, Amico KR, et al. Preexposure prophylaxis for HIV infection integrated with municipal- and community-based sexual health services. JAMA Intern Med. 2016;176(1):75-84.

24. Marcus JL, Hurley LB, Hare CB, Nguyen DP, Phengrasamy T, Silverberg MJ, Stoltey JE, Volk JE. Preexposure prophylaxis for HIV prevention in a large integrated health care system: adherence, renal safety, and Discontinuation. J Acquir Immune Defic Syndr. 2016;73(5):540-6.

25. Lahuerta M, Zerbe A, Baggaley R, Falcao J, Ahoua L, DiMattei P, Morales F, Ramiro I, El-Sadr WM. Feasibility, acceptability and adherence with short term HIV pre-exposure prophylaxis in female sexual partners of migrant miners in Mozambique. J Acquir Immune Defic Syndr. 2017;76:343-7.

26. Balavoine S, Noret M, Loze B, Pintado C, Leplatois A, Charbonneau P, Moudachirou K, Djessima-Taba A, Niedbalski L, Siguier M, Aslan A, Ponscarme D, Penot P, Gatey C, Clavel F, Crémieux A-C, Lorho F, Dalle E, Parlier S, Delgado J, Veron R, Fonsart J, Delaugerre C, Rozenbaum W, Molina JM. PrEP uptake, safety and efficacy in a hospital-based clinic in Paris. Paris: 9th AIS conference on HIV science. p. 2017.
27. Zablotska IV, S Bloch M, Carr A, Foster R, Grulich A, Guy R, McAllister JO, C Poynten M, Templton D. No HIV infections despite high-risk behaviour and STI incidence among gay/bisexual men taking daily pre-exposure prophylaxis (PrEP): the PRELUDE demonstration project. Paris: 9th AIS conference on HIV science. p. 2017.

28. Vaccher SM, M Grulich AE, Ooi C, Carr A, Haire BG, Sctdhmclz I. Very high adherence to HIV PrEP over one year confirmed by four measures in an open-label demonstration project (PrELUDE) in NSW, Australia. Paris: 9th IAS conference on HIV science. p. 2017.

29. Gafos MW, E White D, Clarke A, Apea V, Brodnicki E, Mackie NS, A Schembri G, Lacey C, Horne R, Dunn D, McCormack S. Adherence intentions, longterm adherence and HIV acquisition among PrEP users in the PROUD openlabel randomised control trial of PrEP in England. Paris: 9th AIS conference on HIV science. p. 2017.

30. Gill KD, J Gray G, Pidwell T, Kayamba F, Bennie T, Myer L, Johnson LS, H Slack C, Elharrar V, Strode A, Rooney J, Bekker L. Pluspills: an open label, safety and feasibility study of oral pre-exposureprophylaxis (PrEP) in 15-19 year old adolescents in two sites in South Africa. Paris: 9th AIS conference on HIV science. p. 2017.

31. Choopanya K, Martin M, Suntharasamai $P$, Sangkum U, Mock $P$, Leethochawalit M, Chiamwongpaet S, Kitisin P, Natrujirote $P$, Kittimunkong $S$, et al. Antiretroviral prophylaxis for HIV infection in injecting drug users in Bangkok, Thailand (the Bangkok Tenofovir study): a randomised, doubleblind, placebo-controlled phase 3 trial. Lancet. 2013;381(9883):2083-90.

32. King HL, Keller SB, Giancola MA, Rodriguez DA, Chau JJ, Young JA, Little SJ, Smith DM. Pre-exposure prophylaxis accessibility research and evaluation (PrEPARE study). AIDS Behav. 2014;18(9):1722-5.

33. Kesler MA, Kaul R, Myers T, Liu J, Loutfy M, Remis RS, Gesink D. Perceived HIV risk, actual sexual HIV risk and willingness to take pre-exposure prophylaxis among men who have sex with men in Toronto, Canada. AIDS Care. 2016;28(11):1-8.

34. Merchant RC, Corner D, Garza E, Guan W, Mayer KH, Brown L, Chan PA. Preferences for HIV pre-exposure prophylaxis (PrEP) information among men-who-have-sex-with-men (MSM) at community outreach settings. J Gay Lesbian Ment Health. 2016;20(1):21-33.

35. Kibengo FM, Ruzagira E, Katende D, Bwanika AN, Bahemuka U, Haberer JE, Bangsberg DR, Barin B, Rooney JF, Mark D, et al. Safety, adherence and acceptability of intermittent tenofovir/emtricitabine as HIV pre-exposure prophylaxis (PrEP) among HIV-uninfected Ugandan volunteers living in HIVserodiscordant relationships: a randomized, clinical trial. PLoS One. 2013;8(9):e74314.

36. Bekker L-G, Hughes J, Amico R, Roux S, Hendrix C, Anderson PL, Dye B, Elharrar V, Sirratt MJ, Grant R. HPTN 067/ADAPT Cape Town: a comparison of daily and nondaily PrEP dosing in African women: Conference on retroviruses and opportunistic infections, Seattle. p. 2015

37. Frankis J, Young I, Flowers $P, M c D a i d ~ L$. Who will use pre-exposure prophylaxis (PrEP) and why?: understanding PrEP awareness and acceptability amongst men who have sex with men in the UK - a mixed methods study. PLoS One. 2016;11(4):e0151385.

38. Mutua G, Sanders E, Mugo P, Anzala O, Haberer JE, Bangsberg D, Barin B, Rooney JF, Mark D, Chetty P, et al. Safety and adherence to intermittent pre-exposure prophylaxis (PrEP) for HIV-1 in African men who have sex with men and female sex workers. PLoS One. 2012;7(4):e33103.

39. van de Wijgert J, McCormack S. Vaginal dysbiosis and pre-exposure prophylaxis efficacy. Lancet HIV. 2017;4(10):e427-9.

40. Heffron R, McClelland RS, Balkus JE, Celum C, Cohen CR, Mugo N, Bukusi E, Donnell D, Lingappa J, Kiarie J, et al. Efficacy of oral pre-exposure prophylaxis (PrEP) for HIV among women with abnormal vaginal microbiota: a post-hoc analysis of the randomised, placebo-controlled partners PrEP study. Lancet HIV. 2017;4(10):e449-56.

41. Selinger C, Kirtane A, Abouzid O, Langer R, Traverso CG, Bershteyn A. Anticipated adherence, efficacy, and impact of weekly oral preexposure prophylaxis: Conference on retroviruses and opportunistic infections, Seattle. p. 2017.

42. The Stigma Factor [http://www.washingtontimes.com/news/2008/aug/6/ the-stigma-factor/].

43. Att leva med hiv i sverige. In. Järfälla: Folkhälsomyndigheten; 2016.

44. van der Straten A, Stadler J, Montgomery E, Hartmann M, Magazi B, Mathebula F, Schwartz K, Laborde N, Soto-Torres L. Women's experiences with oral and vaginal pre-exposure prophylaxis: the VOICE-C qualitative study in Johannesburg, South Africa. PLoS One. 2014;9(2):e89118.

45. Van der Elst EM, Mbogua J, Operario D, Mutua G, Kuo C, Mugo P, Kanungi J, Singh S, Haberer J, Priddy F, et al. High acceptability of HIV pre-exposure 
prophylaxis but challenges in adherence and use: qualitative insights from a phase I trial of intermittent and daily PrEP in at-risk populations in Kenya. AIDS Behav. 2013;17(6):2162-72.

46. Trust TH. Shh... No talking: LGBT-inclusive Sex and Relationships Education in the UK. London: Terrence Higgins Trust; 2016.

47. Scotland H. HIV and Education: Guaranteeing lessons for all. Edinburgh, Scotland: HIV Scotland; 2017.

48. Sex and HIV Education [https:/www.guttmacher.org/state-policy/explore/ sex-and-hiv-education]

49. UNAIDS. AIDS by the Numbers. Geneva: UNAIDS; 2016.

50. Daughtridge GW, Conyngham SC, Ramirez N, Koenig HC. I am men's health: generating adherence to HIV pre-exposure prophylaxis (PrEP) in young men of color who have sex with men. J Int Assoc Provid AIDS Care. 2015;14(2):103-7.

51. Hunter M. The materiality of everyday sex: thinking beyond 'prostitution'. Afr Stud. 2002;61(1):99-120.

52. Hoenigl M, Graff-Zivin J, Little SJ. Costs per diagnosis of acute HIV infection in community-based screening strategies: a comparative analysis of four screening algorithms. Clin Infect Dis. 2016;62(4):501-11.

53. Knox D, Tan D, Harrigan P, Anderson P. HIV-1 infection with multiclass resistance despite preexposure prophylaxis (PrEP). Boston: Conference on retroviruses and opportunistic infections. p. 2016.

54. Hosek SG, Siberry G, Bell M, Lally M, Kapogiannis B, Green K, Fernandez MI, Rutledge B, Martinez J, Garofalo R, et al. The acceptability and feasibility of an HIV preexposure prophylaxis (PrEP) trial with young men who have sex with men. J Acquir Immune Defic Syndr. 2013;62(4):447-56.

55. Anand T, Kerr SJ, Apornpong T, Nitpolpraset C, Ananworanich J, Phanuphak P, Phanuphak N. Self-perceived' pre-exposure prophylaxis adherence and its relationship to self-reported 'actual adherence' among Thai men who have sex with men and transgender women. Glasgow: HIV Drug Therapy Glasgow; 2016.

56. Macdonald V, Verster A, Baggaley R. A call for differentiated approaches to delivering HIV services to key populations. J Int AIDS Soc. 2017; 20(Suppl 4):21658.

57. Golub SA, Pena S, Hilley A, Pachankis J, Radix A. Brief behavioural intervention increases PrEP drug levels in a real-world setting: Conference on retroviruses and opportunistic infections, Seattle. p. 2017.

58. Marcus JL, Buisker T, Horvath T, Amico KR, Fuchs JD, Buchbinder SP, Grant RM, Liu AY. Helping our patients take HIV pre-exposure prophylaxis (PrEP): a systematic review of adherence interventions. HIV Med. 2014;15(7):385-95.

59. Khosropour CM, Lester RT, Golden MR, Dombrowski JC. Text messaging is associated with improved retention in a clinic-based PrEP program: Conference on retroviruses and opportunistic infections, Seattle. p. 2017.

60. Poushter J. Smartphone ownership and internet usage continues to climb in emerging economies. Pew Research Center: Washington; 2016.

61. The Mobile Economy. Africa 2016. London: GSM Association; 2016.

62. Evidence brief. Pre-exposure prophylaxis for the prevention of HIV in Europe. In: ECDC evidence brief. Stockholm: European Centre for Disease Prevention and Control. p. 2016.

63. Cambiano V, Miners A, Dunn D, McCormack S, Ong KJ, Gill ON, Nardone A, Desai M, Field N, Hart G, et al. Cost-effectiveness of pre-exposure prophylaxis for HIV prevention in men who have sex with men in the UK: a modelling study and health economic evaluation. Lancet Infect Dis. 2017;18:85-94.

64. Moher D, Liberati A, Tetzlaff J, Altman DG, Group P. Preferred reporting items for systematic reviews and meta-analyses: the PRISMA statement. BMJ. 2009;339:b2535.

65. Grinsztejn BH, B Moreira R, Kallas E, Madruga J, Leite I, de Boni R, Anderson P, Liu A, Luz P, Veloso V. High level of retention and adherence at week 48 for MSM and TGW enrolled in the PrEP Brasil demonstration study. Paris: 9th IAS conference on HIV science. p. 2017.

\section{Ready to submit your research? Choose BMC and benefit from:}

- fast, convenient online submission

- thorough peer review by experienced researchers in your field

- rapid publication on acceptance

- support for research data, including large and complex data types

- gold Open Access which fosters wider collaboration and increased citations

- maximum visibility for your research: over $100 \mathrm{M}$ website views per year

At BMC, research is always in progress.

Learn more biomedcentral.com/submissions 